\title{
Ekstrak Metanol Daun Kelor Menurunkan Ekspresi BCL-2, TRAIL-R1, dan Kadar Caspase-3 Jaringan Kolon Tikus yang Diinduksi DMBA
}

\section{Methanol Extract of Moringa oleifera Decrease BCL-2 Expression, TRAIL-R1 and Caspase-3 Level of Rat Colon Tissue Induced DMBA}

\author{
Boy Adventus $S^{1}$, Tinny Endang $H^{2}$ \\ ${ }^{1}$ Program Pendidikan Spesialis Patologi Klinik Fakultas Kedokteran Universitas Brawijaya Malang \\ ${ }^{2}$ Laboratorium Patologi Klinik Fakultas Kedokteran Universitas Brawijaya Malang
}

\begin{abstract}
ABSTRAK
Ekstrak metanol daun kelor atau Moringa oleifera dapat berfungsi sebagai antioksidan, antiproliferasi, maupun antitumor. Penelitian ini bertujuan untuk membuktikan pengaruh pemberian ekstrak methanol daun kelor khususnya varietas NTT terhadap ekspresi protein-protein apoptosis (TRAIL R1, Bcl-2, dan caspase-3) pada jaringan kolon tikus wistar yang diinduksi DMBA. Rancangan eksperimental post test group design dilakukan dilakukan pada 30 ekor tikus wistar yang dipilih secara random acak lengkap. Semua tikus dikondisikan dalam keadaan homogen dan dibagi dalam 5 kelompok perlakuan berdasarkan dosis ekstrak metanol daun kelor var NTT dan DMBA yang diberikan secara peroral dan selanjutnya diamati selama 60 hari. Pemeriksaan TRAIL-R1 dan Bcl-2 dengan metode imunohistokimia (Anti human/mouse/rat Bcl-2 purified mouse monoclonal IgG2 dan Anti-m TRAIL R1 purified Rat monoclonal IgG2A, R\&D system). Pemeriksaan caspase3 dengan metode ELISA (human/mouse caspase-3 Duoset IC ${ }^{\circledR}$ ELISA R\&D System). Data dianalisis dengan uji ANOVA dan korelasi. Hasil menunjukkan pemberian ekstrak metanol daun kelor var NTT memberikan rerata TRAIL R1 yang lebih rendah bermakna pada dosis 20 dan $40 \mathrm{mg} / \mathrm{KgBB}$ namun tidak pada dosis $80 \mathrm{mg} / \mathrm{KgBB}$. Ketiga dosis tersebut juga memberikan rerata $\mathrm{Bcl}-2$ lebih rendah dibanding kontrol positif. Tidak ada hubungan bermakna rerata caspase-3 antar perlakuan dengan $(F=0,375, p=0,824)$. Dapat disimpulkan pemberian ekstrak metanol daun kelor varian NTT dapat menurunkan ekspresi TRAIL-R1 pada dosis 20 dan $40 \mathrm{mg} / \mathrm{KgBB}$ dan ekspresi Bcl-2 pada semua dosis namun tidak berpengaruh terhadap kadar rerata caspase-3 pada jaringan kolon tikus yang diinduksi DMBA.
\end{abstract}

Kata Kunci: Bcl-2, caspase-3, daun kelor, DMBA, kanker, TRAIL-R1

\begin{abstract}
Methanol extract of Moringa oleifera leaffunctioned as antioxidant, antiproliferation, or antitumor. This study purposes to confirm the effect of methanol extract of Moringa oleifera leaf, specifically NTT variety, to protein apoptosis expression (TRAIL R1, BCl-2, dan caspase-3) on wistar rat colon tissue induced by DMBA. Experimental research using post test group design on 30 wistar rat selected complete randomly. All rats homogenously conditioned and divided into 5 group based on the methanol extract of Moring oleifera var NTT dose and DMBA, given orally and observed for 60 days. TRAIL-R1 and bcl2 examination using immunohistochemistry (Anti human/mouse/rat bcl-2 purified mouse monoclonal IgG2 dan Anti-m TRAIL R1 purified Rat monoclonal IgG2A, R\&D system), while Caspase-3 examination using ELISA method (human/mouse caspase-3 Duoset IC ${ }^{\circledast}$ ELISA R\&D System). Data analysis was using ANOVA test and correlation. Result showed that group of methanol extract of Moringa oleifera var NTT, had TRAIL R1 lower on dose of 20 \& $40 \mathrm{mg} / \mathrm{kg}$ body weight, but not in the dose of $80 \mathrm{mg} / \mathrm{kg}$ body weight. Those three doses also, gave Bcl-2 lower then positive control. There's no significant correlation between average of caspase-3 among treatment $(F=0,375, p=0,824)$. It can be concluded that methanol extract of Moringa oleifera var NTT decreases TRAIL-R1 expression on dose 20 \& $40 \mathrm{mg} / \mathrm{kg}$ body weight and Bcl-2 expression on all doses but has no effect on average of caspase-3 of rat colon tissue induced by DMBA.
\end{abstract}

Keywords: Bcl-2, cancer, caspase-3, DMBA, Moringa oleifera leaf, TRAIL-R1

Jurnal Kedokteran Brawijaya, Vol. 27, No. 4, Agustus 2013; Korespondensi: Tinny Endang H. Laboratorium Patologi Klinik Fakultas Kedokteran Universitas Brawijaya Malang, Jl. Veteran Malang Tel. (0341) 567192 Email: tinnyendang@yahoo.com 


\section{PENDAHULUAN}

Kanker kolorektal (KKR) adalah tumor ganas yang ditemukan di kolon dan rektum. Penyakit ini telah menjadi penyebab kematian kedua terbesar akibat kanker diantara orang dewasa di negara Amerika Serikat. Pada tahun 2008, WHO mencatat bahwa KKR menyebabkan 610.000 kematian di seluruh dunia. Di Indonesia, insiden KKR termasuk dalam 5 besar kanker yang banyak ditemukan. Insiden KKR yang ditemukan di berbagai sentra-sentra laboratorium patologi di seluruh wilayah Indonesia cenderung memperlihatkan angka yang hampir sama (1$3)$.

Lebih dari 50\% penyebab neoplasma adalah akibat defek pada mekanisme apoptosis sel-nya. Beberapa kelainan genetik pada jalur apoptosis sudah diketahui dapat memicu terbentuknya kanker. Terdapat tiga jenis protein yang terlibat dalam mekanisme apoptosis. Protein prosurvival Bcl-2 (B cell lymphoma-2) yang merupakan suatu protein antiapoptosis yang berperan untuk menghambat apoptosis pada jalur mitokondria (intrinsik) sehingga akan meningkatkan daya survival sel. Protein kedua adalah death ligands (TRAIL, Fas) yang berikatan dengan TRAIL-R1 (TNF-related apoptosis inducing ligand receptor 1) yang akan mengaktifkan apoptosis melalui jalur ekstrinsik. Protein terakhir adalah caspase-3 yang merupakan kunci untuk memulai proses kaskade apoptosis sel melalui jalur intrinsik maupun ekstrinsik (46).

Penelitian eksperimental induksi kanker terhadap tikus percobaan dengan menggunakan zat karsinogenik sudah lazim dikerjakan lebih dari 80 tahun terakhir. Jenis tikus yang paling sering digunakan dalam eksperimental laboratorium adalah strain Rattus norvegicus (tikus wistar). Beberapa bahan-bahan karsinogen sering digunakan untuk menginduksi kanker pada tikus diantaranya adalah polycyclic aromatic hydrocarbon (PAH) dan yitrium radioaktif. Karsinogen dari golongan PAH yang paling poten adalah 7,12dimethylbenz[a]anthracene (DMBA) dan sudah sangat sering digunakan untuk menginduksi kanker pada tikus percobaan, diantaranya kanker kelenjar mamma, kanker kulit, dan kanker kolon. Penggunaan DMBA pada penelitian ini diharapkan dapat menginduksi karsinoma melalui defek jalur apoptosis setelah diberikan secara peroral yaitu melalui efek toksik langsung zat ini terhadap jaringan kolon tikus wistar (7).

Ekstrak methanol daun kelor telah diketahui memiliki kandungan nutrien-nutrien yang berperan untuk mencegah proses keganasan. Kadar antioksidan methanol (quercetin dan kaemferol) lebih tinggi dibandingkan tanaman lain. Antioksidan telah lama diketahui dapat menetralkan gugus superoxyl dan peroxyl dari radikal bebas sehingga dapat mencegah kanker. Selain itu, terdapat juga zat yang bersifat antiproliferasi dan antitumor yaitu 4-( $\alpha$-L-rhamnopyranosyloxy)benzylglucosinolat \& niazimicin. Zat ini sudah diketahui dapat mengakibatkan apoptosis pada HeLa cell namun bersifat proliferatif pada limfosit normal sehingga daun kelor ini sangat potensial untuk dipakai sebagai pengobatan kanker (8-10).

Penelitian mengenai efek pemberian ekstrak daun kelor varietas Nusa Tenggara Timur (NTT) terhadap sel-sel kanker belum pernah dilaporkan. Dari segi kualitas, tanaman kelor ini merupakan tanaman kelor kualitas unggul baik dari segi jenis kandungannya, ketahanan terhadap penyakit, dan ketahanan hidup pada daerah tropis. Dengan melihat efek secara umum daun kelor terhadap sel kanker yang telah diteliti sebelumnya, maka penelitian ini mencoba untuk meneliti apakah efek anti kanker tersebut juga berlaku untuk daun kelor varietas NTT. Efek daun kelor tersebut diuji pada jaringan kolon tikus yang diinduksi DMBA apakah ada pengaruhnya terhadap ekspresi ataupun kadar dari protein-protein apoptosis (11). Pada penelitian ini dinilai pengaruh pemberian ekstrak methanol daun kelor varietas NTT terhadap tikus wistar yang diinduksi dengan DMBA dengan mengukur ekspresi TRAIL-R1, Bcl-2, dan kadar caspase-3 yang diekspresikan oleh jaringan kolon.

\section{METODE}

\section{Desain Penelitian}

Penelitian ini merupakan penelitian eksperimental dengan rancangan eksperimen sederhana (post test control group design). Sebanyak 30 ekor tikus wistar dibagi menjadi 5 kelompok (I sampai dengan 5) secara random. Tiap kelompok terdiri dari 6 tikus.

Untuk kelompok 1 (kontrol negatif), tikus hanya diberi pakan normal (standar) saja. Kelompok 2 hingga 5 diberi diet normal dan induksi DMBA sebanyak $10 \mathrm{mg} / \mathrm{kgBB} /$ hari dengan sonde per oral tiap jam 10 pagi selama 44 hari. Setelah hari ke 44, kelompok 2 diberi diet normal tanpa pemberian ekstrak metanol daun kelor. Kelompok 3 (perlakuan I) diberi ekstrak metanol daun kelor dengan disonde per oral dengan dosis $20 \mathrm{mg} / \mathrm{kgBB} /$ hari pada diet normal. Kelompok 4 (perlakuan II) diberi ekstrak methanol daun kelor dengan disonde per oral dengan dosis 40 $\mathrm{mg} / \mathrm{kgBB} /$ hari pada diet normal per hari. Kelompok 5 (perlakuan III) diberi ekstrak metanol daun kelor dengan disonde per oral dengan dosis $80 \mathrm{mg} / \mathrm{kgBB} /$ hari pada diet normal per hari. Diet ekstrak daun kelor pada semua kelompok diberikan selama 60 hari, sedangkan pakan normal saja selama 105 hari.

\section{Proses Ekstraksi Daun Kelor}

Tepung daun kelor varietas NTT yang digunakan yaitu tepung daun kelor yang diproduksi oleh PT. Timor Mulia Sentosa. Proses ekstraksi menggunakan 42 gram dari tepung dan daun kelor yang disuspensikan dalam methanol 80\% sampai volume $900 \mathrm{ml}$. Kemudian ekstrak diaduk secara mekanis selama 12 jam dalam temperatur ruangan $\left(25^{\circ} \mathrm{C}\right)$. Solid kemudian dipindahkan dengan sentrifugasi (4000 g selama 10 menit) dan supernatannya diambil. Hasil ekstrak kemudian disimpan pada suhu $4^{\circ} \mathrm{C}$ untuk proses lebih lanjut (12).

Pemeriksaan TRAIL-R1 dan BCl-2 dengan Metode Imunohistokimia (Anti human/mouse/rat bcl-2 purified mouse monoclonal IgG2 dan Anti-m TRAIL R1 purified Rat monoclonal lgG2A, R\&D system).

Jaringan yang akan dipakai dilakukan diseksi, sekitar 4$5 \mu \mathrm{m}$, kemudian ditetesi air dan dikeringkan dengan memiringkan kaca objek secara vertikal untuk memediasi adhesi jaringan pada kaca objek. Dilakukan pemanasan slide selama 30 menit pada suhu $60^{\circ} \mathrm{C}$ atau $37^{\circ} \mathrm{C}$ selama semalam. Selanjutnya dilakukan deparafinisasi $x y / o / 1$ (Merck) 10 menit, xylo/2 5 menit, serta alkohol absolut, alkohol 95\%, alkohol 90\%, alkohol 80\%, alkohol 70\%, masing-masing 5 menit. Kemudian slide ditetesi dengan PBS PH 7,4 (10 menit) kemudian dilap dengan kertas tisu 
kemudian ditetesi dengan larutan Tris EDTA (10 menit) kemudian dilap dengan kertas tissue. Dilakukan bloking dengan BSA $1 \%$ selama 30 menit dicuci dengan PBS ( 3 x 5 menit) kemudian dilap dengan kertas tisu. Kemudian ditetesi antibodi primer (monoclonal mouse anti-human bcl-2/polyclonal goat antibody dcTRAIL-R1) yang diencerkan dengan PBS dan lauran Twin 0,1\% 1 : 50. Sediaan diinkubasi selama 24 jam dalam suhu $4^{\circ} \mathrm{C}$, kemudian diuci dengan PBS PH 7,4 (3 x 5 menit) dilap dengan kertas tisu. Selanjutnya sediaan ditetesi antibodi sekunder IgG Biotin dalam PBS 1 jam pada temperatur ruang, lalu dicuci dengan PBS pada PH 7,4 (3 x 5 menit) kemudian dilap dengan kertas tisu. Selanjutnya sediaan ditetesi DAB 20-40 menit (coklat), dicuci kembali dengan aquadest ( $3 \times 5$ menit) kemudian dilap dengan kertas tissue. Dilakukan counterstain dengan meyer hematoxylen (biru) 10 menit, lalu dicuci dengan air secukupnya dan keringkan dengan udara. Setelah itu dimounting dengan entelan.

Sel-sel yang mengekspresikan protein $\mathrm{Bcl}-2$ ataupun TRAIL-R1 adalah sel-sel yang berwarna kecoklatan pada pengecatan imunohistokimia. Perhitungan sel-sel yang mengekspresi $\mathrm{Bcl}-2$ dan TRAIL-R1 adalah dengan menghitung sel yang berwarna coklat pada sitoplasma sel jaringan kolon dan dilakukan pada pembesaran mikroskop P1000x (P10x lensa okuler dan P100x lensa objektif). Dihitung sebanyak 200 sel dan dibedakan menurut jenis sel-nya (sel epitel kuboid kelenjar atau sel epitel skuamosa permukaan mukosa usus). Jumlah sel-sel yang diekspresikan dilaporkan dalam persen .

Pemeriksaan Caspase-3 dengan Metode ELISA (human/mouse caspase-3 Duoset IC ${ }^{\circledR}$ ELISA R\&D System).

Sebanyak $100 \mathrm{mg}$ sampel jaringan kolon cancer diambil lalu digerus. Ditambahkan lysis buffer BFF PMFS kemudian pindahkan ke tube kemudian dicampur melalui Vortex selama kurang lebih 5 detik lalu masukkan dalam lemari es $3{ }^{\circ} \mathrm{C}$ selama 10 menit. Dilakukan sentrifugasi selama 10 menit dengan microcentrifuge 5000 rpm. Supernatan (ekstrak sitosol) dipindahkan kedalam tube dan letakkan dalam es. Setelah sediaan dikeluarkan dari refrigerator 2$8^{\circ} \mathrm{C}$, diletakkan kit selama 30 menit pada suhu ruang sebelum digunakan. Selanjutnya ditetapkan standar dan sample dilution dalam 96-well plate yang bersih dan diencerkan $20 x$ wash solution ke $1 x$ wash solution. Diluted standart $50 \mu \mathrm{l}$ dipindahkan ke standard wells, diluted sample $50 \mu \mathrm{l}$ (10 $\mu \mathrm{l}$ sampel dengan $40 \mu \mathrm{l}$ sample diluents) ke sample wells, sample diluents saja ke blank wells. Plate diinkubasi selama 30 menit dalam inkubator $37^{\circ} \mathrm{C}$. Cairan dipindahkan dari wells sebanyak mungkin. Wells diisi dengan washing solution, digoyang atau dikocok plate pada oscillating shaker jika tersedia selama 1 menit, washing solution dipindahkan dan dibersihkan sisa cairan dengan kertas absorbent. Pembersihan diulang sebanyak 4 kali, ditambahkan HRP-conjugated antibody $50 \mu \mathrm{l}$ ke setiap wells, kecuali blank well. Dilakukan mix dengan cara shaking dengan lembut dan diinkubasi selama 30 menit dalam suhu $37^{\circ} \mathrm{C}$ kemudian dibersihkan dengan plate atau strip. Selanjutnya ditambahkan chromogenic substrate A dan B; substrate A $50 \mu \mathrm{l}$ dan substrate B $50 \mu \mathrm{l}$ ke setiap well kemudian dicampur dengan lembut, dan diinkubasi selama 15 menit dalam suhu $37^{\circ} \mathrm{C}$. Stop Solution $50 \mu \mathrm{l}$ ditambahkan dengan segera ke setiap well di bagian atas reaksi (warna biru berubah jadi kuning). Selanjutnya dilakukan pengukuran optical density (OD) pada $405 \mathrm{~nm}$ selama 15 menit. Dilakukan pembuatan kurva standar dengan cara merencanakan OD 450 ratarata untuk setiap standar pada sumbu $Y$ terhadap konsentrasi pada sumbu- $X$, menggambar kecocokan loglog kurva melalui titik-titik), menghitung persamaan regresi linier. Contoh nilai OD dan regresi persamaan digunakan untuk menghitung konsentrasi sampel yang sesuai.

Hasil pengukuran ekspresi Bcl-2, TRAIL-R1, dan caspase-3 jaringan kolon tikus kontrol dan perlakuan dianalisis secara statistik dengan menggunakan program SPSS 16 dengan tingkat signifikansi 0,05 $(p=0,05)$ dan taraf kepercayaan $95 \%$ $(\alpha=0,05)$. Analisis dilakukan dengan hipotesis komparatif dan korelatif setelah diuji normalitas rerata dan homogenitas varian untuk ketiga parameter penelitian.

\section{HASIL}

Pada awal penelitian, sampel tikus wistar yang diikutkan ke dalam penelitian berjumlah 30 ekor. Setelah pemberian DMBA per oral (sonde) selama 44 hari, 2 ekor tikus dimatikan dengan pembiusan eter untuk pembuktian telah terbentuknya KKR pada kolon tikus kontrol positif (kelompok II). Pembuktian ini dilakukan pada hari ke-30 dan hari ke-44. Selanjutnya dilakukan pemeriksaan histologi jaringan kolon dengan pengecatan Meyer hematoxylen (Gambar 1). Hasil pemeriksaan jaringan kolon tikus wistar $\mathrm{K}+$ mengesankan suatu proliferasi displastik ringan dari sel sel kripta usus besar belum terjadi penetrasi ke mukosa muskularis maupun submukosa.

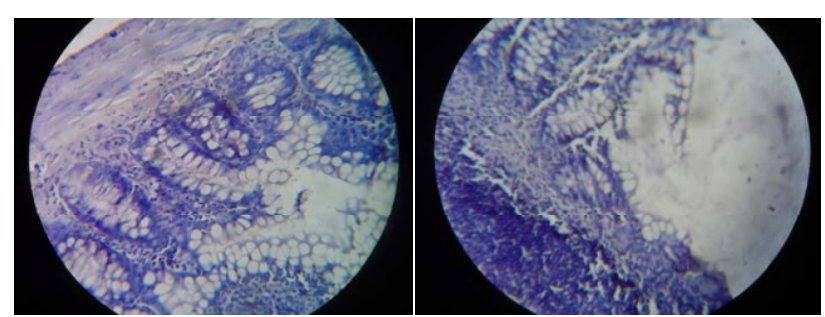

Gambar 1. Proliferasi displastik pada kolon tikus wistar kelompok II (kontrol positif)

A \& B: Proliferasi ringan displastik arsitektur dari sel-sel kripta usus besar yang disertai dengan inflamasi ringan (anak panah kuning) belum penetrasi ke mukosa muskularis maupun submukosa (P 1000x)

Setelah 60 hari kemudian (paska pemberian ekstrak metanol daun kelor), semua tikus percobaan dimatikan untuk dilakukan pemeriksaan TRAILR1,caspase-3,dan Bcl2 pada jaringan kolon-nya (Tabel 1). Hasil uji Kruskall Walis menunjukkan terdapat perbedaan signifikan $\mathrm{Bcl}-2$ dan TRAIL R1 pada berbagai dosis ekstrak daun kelor $(p=0,04$, $\mathrm{p}=0,02$ ) dilanjutkan dengan menggunakan uji MannWhitney. Hasil analisa statistik menunjukkan adanya perbedaan yang bermakna pada ekspresi Bcl-2 pada perlakuan tikus yang diberikan pakan normal saja dengan tikus yang diberikan diet normal dengan induksi DMBA. Ekspresi $\mathrm{Bcl}-2$ pada tikus dengan induksi DMBA lebih rendah secara signifikan sesudah diberikan ekstrak daun kelor pada tiga dosis ekstrak daun kelor $(p=0,004,0,047$, $0,026)$ hingga sama dengan kondisi normal. Tidak ada perbedaan ekpresi Bcl-2 antara ketiga dosis tersebut $(0,14$, $0,14,0,924)$.

Ekspresi TRAIL-R1 pada induksi DMBA lebih tinggi secara signifikan dibandingkan kondisi normal. Pemberian 
Tabel 1. Kadar TRAILR1, caspase-3,dan Bcl-2 pada jaringan kolon dalam berbagai dosis

\begin{tabular}{|c|c|c|c|c|}
\hline Kelompok Perlakuan & $\begin{array}{c}N \\
(28)\end{array}$ & $\begin{array}{c}\mathrm{Bcl}-2 * \\
(\text { rerata } \pm \mathrm{SD}) \%\end{array}$ & $\begin{array}{c}\text { TRAIL-R1* } \\
\text { (rerata } \pm \text { SD) } \% \\
\end{array}$ & $\begin{array}{c}{\text { Caspase }-3^{+}} \\
\text {(rerata } \pm \mathrm{SD}) \mathrm{ng} / \mathrm{ml}\end{array}$ \\
\hline Diet normal & 6 & $0,0000^{a}$ & $0,0000^{a}$ & $5,1567 \pm 2,02$ \\
\hline Diet normal +induksi DMDA & 4 & $4,8750 \pm 1,44^{b}$ & $32,1250 \pm 1,70^{b}$ & $5,0475 \pm 0,62$ \\
\hline Ekstrak metanol $20 \mathrm{mg} / \mathrm{kgBB}$ & 6 & $0,0000^{\mathrm{a}}$ & $12,9167 \pm 10,11^{c}$ & $5,8833 \pm 1,49$ \\
\hline Ekstrak metanol $40 \mathrm{mg} / \mathrm{kgBB}$ & 6 & $1,4167 \pm 2,46^{a}$ & $11,1667 \pm 2,94^{c}$ & $5,5717 \pm 0,81$ \\
\hline Ekstrak metano $80 \mathrm{mg} / \mathrm{kgBB}$ & 6 & $1,2500 \pm 2,09^{a}$ & $18,5833 \pm 11,89^{c}$ & $5,8617 \pm 1,61$ \\
\hline
\end{tabular}

Keterangan: ${ }^{\mathrm{abc}}$ notasi yang berbeda menunjukkan perbedaan signifikan.

ekstrak metanol daun kelor pada ketiga dosis ( $20 \mathrm{mg}, 40$ $\mathrm{mg}, 80 \mathrm{mg}$ ) terbukti memberikan gambaran ekspresi TRAIL-R1 yang lebih rendah secara bermakna dibandingkan kondisi induksi DMBA (kontrol positif). Tidak ada perbedaan ekspresi TRAIL-R1 pada ketiga dosis tersebut. Hasil uji ANOVA yang dilakukan pada parameter caspase-3 menunjukkan bahwa tidak terdapat pengaruh yang signifikan antar perlakuan dengan kadar caspase-3 yang terdapat pada jaringan kolon tikus wistar $(\mathrm{F}=0,375$, $p=0,824)$.

\section{DISKUSI}

Penelitian ini bertujuan untuk mengetahui pengaruh pemberian ekstrak metanol daun kelor terhadap kadar caspase-3, Bcl-2, dan TRAIL R1 pada jaringan kolon tikus wistar model kanker kolon. Tikus wistar model kanker kolon dibuat dengan memberikan karsinogen DMBA 10 mg per hari selama 44 hari. Hasil pemeriksaan jaringan kolon tikus wistar $\mathrm{K}+$ mengesankan suatu proliferasi displastik ringan dari sel-sel kripta usus besar dan belum terjadi penetrasi ke mukosa muskularis maupun submukosa. Hal ini menunjukkan bahwa pemberian DMBA $10 \mathrm{mg}$ setiap hari per oral melalui sonde selama 44 hari belum cukup untuk membuat tikus wistar model kanker kolon. DMBA merupakan karsinogen golongan aromatic amine yang memiliki potensi karsinogenik ringan-sedang. Pemberian DMBA per oral dalam kurun waku yang relatif singkat (44 hari) diduga sebagai penyebab tidak terbentuknya tikus wistar model kanker kolon. Rosenberg et al mencatat bahwa golongan aromatic amine yang lain seperti DMAB (3,2-dimethyl-4aminobiphenyl) dapat menimbulkan adenokarsinoma maupun adenoma pada tikus eksperimen F344 dengan dosis $100 \mathrm{mg} / \mathrm{kgBB}$ secara subkutan selama 20 minggu (14).Penelitian yang dilakukan Bissahoyo et al memperbaikinya dengan menemukan bahwa pemberian melalui intraperitoneal ternyata menghasilkan kanker kolon dengan ukuran yang lebih besar dari pada melalui injeksi subkutan (15). Pemberian melalui oral seperti yang dikerjakan pada penelitian ini berdampak terhadap bioavailibilitas karsinogen dalam darah tikus lebih rendah dibandingkan melalui subkutan sehingga tentu saja akan mengurangi efektivitas DMBA dalam menginduksi kanker. Supaya dapat berpotensi sebagai karsinogen, DMBA semestinya dimetabolisme di hepar tikus menjadi metabolit 7-hydroxy-DMBA oleh karena metabolit tersebut yang bersifat reaktif oksidan terhadap DNA sel. Beberapa studi memperlihatkan bahwa senyawa DMBA yang tidak mengalami biotransformasi menjadi 7hydroxy-DMBA gagal dalam menyebabkan karsinoma (10). Ekspresi rerata TRAIL R1 pada tiga dosis ekstrak metanol daun kelor $(20 \mathrm{mg}, 40 \mathrm{mg}$, dan $80 \mathrm{mg}$ ) tidak menunjukkan perbedaaan yang bermakna. Pengaruh pemberian ekstrak metanol daun kelor terhadap ekspresi TRAIL R1 secara bermakna terlihat pada tikus wistar K+ dengan $\mathrm{PI}$ dan $\mathrm{K}+$ dengan $\mathrm{P}$ II masing-masing dengan nilai $\mathrm{p}$ 0,01 dan 0,011. Telah diketahui bahwa TRAIL R1 berperan dalam jalur ekstrinsik apoptosis dengan berinteraksi dengan death ligand yaitu TNF- $\alpha$, TRAIL, atau Fas. Pemberian DMBA sebagai reaktif oksidan terbukti berhubungan dengan ekspresi TRAIL R1 yang meningkat pada jaringan kolon tikus wistar. Penelitian yang dilakukan Morissette et al pada jaringan alveoli paru penderita emphysema yang perokok juga memperlihatkan peningkatan kadar ekspresi TRAIL R1 dan hal ini berkaitan dengan efek oksidan reaktif dari asap rokok dan proses inflamasi yang merusak jaringan paru (16). Dengan pemberian ekstrak daun kelor terbukti sangat efektif dalam menyebabkan penurunan kadar rerata TRAIL R1 paska induksi DMBA pada penelitian ini. Dengan kadar ekstrak daun kelor $80 \mathrm{mg}$ yaitu pada populasi kontrol positif dengan ekstrak metanol daun kelor dosis $80 \mathrm{mg}$ ternyata diperoleh hasil tidak berbeda bermakna yang mungkin dampak dari efek toksis dari ekstrak metanol daun kelor dalam pengurangan reaksi inflamasi. Sampai saat ini belum diketahui dosis pemberian ekstrak methanol daun kelor yang toksis. Dari hasil penelitian ini diduga dengan kadar $80 \mathrm{mg}$ per hari selama 60 hari berturut-turut telah berdampak terhadap peningkatan ekspresi TRAIL R1 yang ekspresinya tidak berbeda dengan kondisi induksi DMBA.

Penelitian-penelitian sebelumnya telah diketahui kalau ekstrak methanol daun kelor memiliki potensi sebagai antiinflamasi $(12,16)$. Ekspresi rerata $\mathrm{Bcl}-2$ antar perlakuan ekstrak daun kelor pada tiga dosis $20 \mathrm{mg}, 40 \mathrm{mg}$, dan $80 \mathrm{mg}$ tidak menunjukkan adanya perbedaan yang bermakna. Perbedaan ekspresi protein $\mathrm{Bcl}-2$ terlihat antara kondisi induksi DMBA dengan pemberian ekstrak daun metanol pada tiga dosis. Hal ini menunjukkan bahwa ada pengaruh yang siknifikan dari penurunan ekspresi protein $\mathrm{Bcl}-2$ sesudah pemberian ekstrak metanol daun kelor menurut dosis yang berbeda-beda. Protein Bcl-2 merupakan protein yang berperan sebagai anti-apoptosis yang berperan untuk mengatur/menghambat proses apoptosis. Protein ini dapat menghambat aktivasi BAX yang diakibatkan adanya signal apoptosis dari luar sel (misalnya: reaktif oksidan, radiasi, maupun zat kimia yang merusak DNA). Dari hasil penelitian ini dapat diduga bahwa setelah pemberian ekstrak metanol daun kelor terjadi perbaikan/resolusi dari proses inflamasi yang diakibatkan DMBA sehingga respon sel-sel jaringan kolon tikus wistar untuk mengeluarkan protein $\mathrm{Bcl}-2$ kembali normal. Efek antiinflamasi bersumber dari molekul aurantiamide acetate dan 1,3 dibenzyl urea yang sudah diuji sebagai antiinflamasi/antiartritis melalui inhibisi TNFalpha dan IL-2 $(5,16,17)$. 
Caspase-3 merupakan suatu protein yang berperan sebagai eksekutor untuk menginisiasi proses apoptosis baik melalui jalur intrinsik maupun jalur ekstrinsik. Berdasarkan hasil uji ANOVA kadar caspase-3 menurut masing-masing perlakuan diperoleh hasil yang tidak berbeda bermakna. Hasil ini menunjukkan bahwa pemberian ekstrak methanol daun kelor dengan dosis berturut-turut $20 \mathrm{mg}, 40 \mathrm{mg}, 80 \mathrm{mg}$ tidak menunjukkan efek peningkatan dari rerata kadar caspase-3 jaringan. Sesuai dengan hipotesis pada penelitian ini peningkatan rerata kadar caspase-3 pada masing-masing perlakuan terhadap jaringan kolon kontrol negatif (tikus wistar normal) memiliki arti bahwa jaringan kolon tersebut mengalami proses apoptosis yang lebih tinggi dibandingkan jaringan normal dengan demikian pemberian ekstrak metanol daun kelor mempunyai pengaruh terhadap peningkatan proses apoptosis pada jaringan kolon tikus wistar model kanker kolon. Hipotesis tersebut tidak terbukti melalui hasil uji ANOVA. Hal ini kemungkinan dikarenakan pemberian DMBA per oral belum mengakibatkan terbentuknya kanker pada kolon tikus wistar tetapi hanya terjadi displasia ringan dan reaksi inflamasi. DMBA bersifat toksik terhadap DNA sel oleh karena ia dapat membentuk ion carbonium yang sangat reaktif sehingga memicu kematian sel dan selanjutnya dapat menginduksi mutasi DNA yang pada akhirnya dapat mengakibatkan kanker. Sel yang mengalami kerusakan/kematian akibat patologis akan mengalami regenerasi melalui proses proliferasi sel yang dipicu oleh sitokin-sitokin, seperti epidermal growth factor (EGF), transforming growth factor (TGF- $\alpha$ ), TGF- $\beta$, dan lainnya.

Dengan paparan DMBA yang terus menerus pada jaringan kolon tikus wistar hanya menghasilkan proliferasi yang displastik dan ditandai dengan perubahan dari morfologi epitel kolon. Peningkatan proliferasi displastik ini sesuai dengan rerata kadar caspase-3 yang tidak berbeda antara masing-masing perlakuan dimana caspase-3 merupakan eksekutor untuk proses apoptosis yang bertolak belakang dengan proses displasia sehingga dengan demikian rerata kadar caspase-3 relatif sama antara tikus wistar kontrol

\section{DAFTAR PUSTAKA}

1. Markowitz SD and Bertagnolli MM. Molecular Basis of Colorectal Cancer. The New England Journal of Medicine. 2009; 361: 2249-2260.

2. World Health Organization. Cancer. (Online) 2008. www.who.int/mediacentre/factsheets /fs297/en/\#. [diakses tanggal 24 Februari 2011].

3. Soeripto, Indrawati, dan Indrayanti. Gastro-intestinal Cancer in Indonesia. Asian Pacific Journal of Cancer Prevention. 2003; 4: 289-296.

4. Yang SY, Sales KM, and Winslet MC. Apoptosis in Colorectal Tumorigenesis and Chemotherapy. In: Chen GG and Lai PBS (Eds). Apoptosis in Carcinogenesis and Chemotherapy. New York: Springer: 2009; p. 75-98.

5. Hotchkiss RS, Strasser A, McDunn JE, and Swanson PE. Cell Death. The New England Journal of Medicine. 2009; 361(16): 1570-1583.

6. Barisic K, Petrik J, and Rumora L. Biochemistry of Apoptotic Cell Death. Acta Pharmaceutika. 2003; positif dengan tikus wistar yang mendapat ekstrak methanol daun kelor 20.40 .80 mg maupun kondisi normal. Hal ini merupakan kelemahan dalam penelitian ini karena tidak berhasil membuat tikus wistar model kanker kolon. Penelitian yang lain yang dilakukan oleh Jonges et al melaporkan bahwa aktivitas caspase-3 berkorelasi dengan sel tumor yang mengalami apoptosis namun aktivitas caspase-3 yang tinggi pada kanker kolon tersebut ternyata belum tentu berisi sel kanker yang mengalami apoptosis paling banyak. Hal tersebut mengindikasikan perbedaan tingkat aktivitas caspase-3 diantara sel-sel kanker. Untuk menilai tingkat apoptosis lebih akurat pada masing-masing perlakuan pada sel kolon tikus wistar dianjurkan untuk melakukan konfirmasi menghitung jumlah sel yang mengalami apoptosis dengan metode imunohistokimia yang mengukur ekspresi M30+. Ekspresi M30+ merupakan produk dari pemecahan keratin-18 yang merupakan pertanda untuk sel epitel yang mengalami apoptosis $(11,18,21)$.

Hasil penelitian ini membuktikan bahwa pemberian ekstrak metanol daun kelor varian NTT dengan dosis berturut-turut $20 \mathrm{mg}$ dan $40 \mathrm{mg} / \mathrm{KgBB}$ selama 60 hari didapatkan penurunan kadar rerata ekspresi protein TRAIL R1 yang bermakna dibanding kontrol positif namun hal ini tidak berlaku untuk dosis daun kelor $80 \mathrm{mg}$. Hal ini diduga akibat efek toksis ekstrak metanol daun kelor sebagai anti inflamasi. Ada penurunan kadar rerata ekspresi protein $\mathrm{Bcl}-2$ yang bermakna antara tikus wistar ekstrak metanol daun kelor dibandingkan dengan kontrol positif. Untuk caspase-3 tidak ada pengaruh pemberian ekstrak daun kelot terhadap kadar rerata caspase-3 walaupun dengan dosis daun kelor yang berbeda.

Pemberian DMBA yang sudah dirancang dalam penelitian ini tidak dapat membentuk tikus model kanker. Untuk itu perlu dilakukan penelitian yang serupa dengan metode pemberian zat karsinogen yang berbeda dengan paparan yang lebih lama, dan rute pemberian melalui intraperitoneal. Dianjurkan menggunakan karsinogen azoxymethane (AOM) atau 1,2-dimethylhydrazine (DMH) yang diberikan secara intraperitoneal selama 25 minggu.

\section{3(3): 151-164}

7. Lynch D, Svobobda J, Putta S, Hofland HEJ, Chem W, and Hansen LA. Mouse Skin Model for Carcinogenic Hazard Identification: Utilities and Challenges. Journal of Toxicologic Pathology. 2007; 35(7): 853-864.

8. Goyal BR, Agrawal BB, Goyal RK, and Mehta AA. Phytopharmacology of Moringa oleifera Lam. ó An Overview. Natural Product Radiance. 2007; 6(4): 347353.

9. Guevara AP, Vargas C, Sakurai H, et al. An Anti-tumor promotor from Moringa oleifera Lam. Mutation Research. 1999; 440(2): 181-188.

10. Nair S and Varalakshmi KN. Anticancer, Cytotoxic Potential of Moringa oleifera Extracts on HeLa cell line. Journal of Natural Pharmaceuticals. 2011; 2(3): 138142.

11. Bharali R, Tabassum J, and Azad MRH. Chemomodulatory Effect of Moringa oleifera Lam, on Hepatic Carcinogen Metabolising Enzymes, Antioxidant Parameters and Skin Papillomagenesis in Mice. Asian Pacific Journal of Cancer Prevention. 2003; 
4(2): 131-139.

12. Khalafalla MM, Abdellatef $\mathrm{E}$, Dafalla $\mathrm{HM}$, et al. Active Principle from Moringa oleifera Lam Leaves Effective Against Two Leukemias and Hepatocarcinoma. African Journal of Biotechnology. 2010; 9(49): 84678471.

14. Rosenberg DW, Giardina C, and Tanaka T. Mouse Models for the Study of Colon Carcinogenesis. Carcinogenesis. 2009; 30(2): 183-196.

15. Bissahoyo A, Pearsall RS, Hanlon K, et al. Azoxymethane is a Genetic Backgrounddependent Colorectal Tumor Initiator and Promoter in Mice: Effects of Dose, Route, and Diet. Toxicological Sciences. 2005; 88(2): 340-345.

16. Morissette MC, Vachon-Beaudoin G, Parent J, Chakir $\mathrm{J}$, and Milot. Increased $\mathrm{p} 53$ level, Bax/Bcl-xl Ratio, and TRAIL Receptor Expression in Human Emphysema. American Journal of Respiratory and Critical Care Medicine. 2008; 178(3): 240-247.
17. Pandey A, Pandey RD, Tripathi $\mathrm{P}$, et al. Moringa Oleifera Lam. (Sahijan)-A Plant with a Plethora of Diverse Therapeutic Benefits: An Updated Retrospection. Medicinal and Aromatic Plants. 2012; 1(1): 1-8.

18. Hoeijmakers JHJ. DNA damage, Aging, and Cancer. The New England Journal of Medicine. 2009; 361(15): 1475-1485.

19. Kumar V and Abbas AK. Cell Injury, Cell Death, and Adaptation. In: Kumar V, Abbas AK, Fausto N, and Mictchell RN (Eds). Robbins Basic Pathology 8th edition. Philadelphia: Elsevier-Saunders; 2007; p. 5965.

20. Talbot I, Price A, and Salto-Tellez M. Biopsy Pathology in Colorectal Disease. 2nd edition. London: Oxford University Press; 2007; p. 301-311 and p. 330-347.13

21. Jonges EJ, Nagelkerke JF, Ensink NG, et al. Caspase-3 Activity as a Prognostic Factor in Colorectal Carcinoma. Laboratory Investigation. 2001; 81(5): 681-688 